\title{
THE ROLE OF FRONTAGE BUILDING TOWARDS ESTABLISHMENT OF PEDESTRIAN AREA IN JL. JENDERAL SUDIRMAN
}

\author{
${ }^{1}$ Marisa Zharfan K. ${ }^{2}$ Dimas Hartawan, S.T., M.T.,. ${ }^{3}$ Adam Ramadhan, M.T. \\ ${ }^{1}$ Student in the Bachelor's (S-1) Study Program in Architecture \\ at Parahyangan Catholic University \\ 2 Senior lecturer in the Bachelor's (S-1) Study Program in Architecture \\ at Parahyangan Catholic University \\ ${ }^{3}$ Senior lecturer in the Bachelor's (S-1) Study Program in Architecture \\ at Parahyangan Catholic University
}

\begin{abstract}
In the early stage of the scenario realization has been done improvements in the alun alun area, also Jl. Jend. Sudirman. In the year 2016 carried out revitalization pedestrian paths on block Jl. Jend. Sudirman. Revitalization of pedestrian paths is preferred because pedestrian paths are the most basic public spaces to facilitate the movement of pedestrians from one place to another. However, the activity on this relatively new pedestrian path affects other names with existing building frontages.

By qualitative method, this research read the pattern of dissemination of activity and condition of frontage of building on research object. This is done to determine whether the frontage of buildings and activities in the outer space have a relationship with each other. From this study found that the activity is not only influenced by the nature and material frontage of the building, but there is also a typology of space formed by the frontage of the building. Typology of space is closely related to the activities that occur in outer space.
\end{abstract}

Key Words: Frontage, Active Frontage, City Furniture, Building Functions, Activities, Outer Space.

\section{PERAN FRONTAGE BANGUNAN TERHADAP PEMBENTUKAN AKTIVITAS RUANG PEJALAN KAKI DI JL. JENDERAL SUDIRMAN}

\author{
${ }^{1}$ Marisa Zharfan K. ${ }^{2}$ Dimas Hartawan, S.T., M.T.,. ${ }^{3}$ Adam Ramadhan, M.T. \\ ${ }^{1}$ Mahasiswa S1 Program Studi Arsitektur Universitas Katolik Parahyangan \\ ${ }^{2}$ Dosen Pembimbing S1 Program Studi Arsitektur Universitas Katolik Parahyangan \\ ${ }^{3}$ Dosen Pembimbing S1 Program Studi Arsitektur Universitas Katolik Parahyangan
}

\begin{abstract}
Abstrak- Pada tahap awal realisasi skenario tadi sudah dilakukan perbaikan pada kawasan alun-alun, juga Jl. Jend. Sudirman. Pada tahun 2016 dilakukan revitalisasi jalur pejalan kaki pada blok Jl. Jend. Sudirman. Revitalisasi jalur pejalan kaki diutamakan karena jalur pejalan kaki merupakan ruang publik yang paling mendasar untuk mempermudah perpindahan pejalan kaki dari satu tempat ke tempat lainnya. Namun, aktivitas pada jalur pedestrian yang terbilang baru ini memengaruhi satusama lain dengan frontage bangunan yang sudah ada.

Dengan metode kualitatif, penelitian ini membaca pola-pola penyebaran aktivitas dan kondisi frontage bangunan pada objek penelitian. Hal ini dilakukan untuk mengetahui apakah frontage bangunan dan aktivitas pada ruang luar memiliki hubungan satu sama lain. Dari penelitian ini ditemukan bahwa aktivitas tidak hanya dipengaruhi oleh sifat dan material frontage bangunan, namun terdapat juga tipologi ruang yang terbentuk oleh frontage bangunan. Tipologi ruang ini memiliki hubungan erat dengan aktivitas yang terjadi pada ruang luar.
\end{abstract}

\footnotetext{
${ }^{1}$ Corresponding Author: marisazharfan@gmail.com
} 
Kata Kunci: Frontage, Active Frontage, Furniture kota, Fungsi Bangunan, Aktivitas, Ruang Luar.

\section{PENDAHULUAN}

Dalam buku Urban Space, Rob Krier menjelaskan bahwa konsep dari ruang kota (tanpa dipengaruhi oleh kriteria estetik) mendorong untuk merujuk semua jenis ruang di antara bangunan pada sebuah kota sebagai ruang kota. Ruang kota secara geometris memiliki beragam elevasi sebagai batasnya. Ruang hanya dapat dibaca dengan jelas dari karakteristik geometris dan kualitas estetisnya. Hal tersebut memungkinkan pengamat secara sadar memandang ruang eksternal sebagai ruang kota.

Sifat berlawanan satu sama lain dari ruang dalam dan ruang luar memiliki kemiripan bukan hanya dari segi fungsi, namun juga wujudnya. Ruang dalam, terlindungi dari cuaca dan lingkungan merupakan simbol dari privat. Ruang luar dapat dilihat sebagai ruang yang terbuka, ruang yang tidak terhalang untuk pergerakan, dengan perpaduan dari area publik, semi publik, dan privat.

Di dalam sebuah ruang kota terdapat 2 komponen yaitu alun-alun dan jalanan. Alunalun dapat terbentuk dari pengelompokan beberapa rumah yang ditata mengitari sebuah ruang terbuka. Penataan yang demikian dapat menciptakan kontrol ruang dalam dengan tingkatan yang sangat baik. Jalanan merupakan produk dari sebaran permukiman disaat sekeliling alunalun utama sudah penuh. Jalanan ini menyediakan kerangka unuk pendistribusian lahan, serta akses menuju lahan tersebut.

Bagaimana bermacam-macam tipe bangunan yang memiliki fasad dengan kesesuaian fungsi dan metode konstruksi tentunya akan memengaruhi ruang sebuah kota. Ruang-ruang positif dan negatif tercipta dari susunan massa muka bangunan. Sebuah Ruang kota yang fisiknya terencana dengan baik (terutama potongan bangunannya), dapat mengundang maupun menolak kontak antar ruang luar dan ruang dalam dalam hal penglihatan maupun pendengaran.

Agar sebuah bangunan dapat mengundang, membutuhkan pandangan yang tidak terhalang, jarak pendek, kecepatan rendah, tetap pada tingkat dan orientasi yang sama terhadap apa yang akan dialami. Bila yang terjadi adalah kebalikan dari yang disebutkan sebelumnya, maka sebuah bangunan akan menolak pengguna jalan untuk berinteraksi dengan ruang di sekitar bangunan.

\section{KAJIAN TEORI}

\subsection{STREET WALL}

Street Wall merupakan tempat di mana ruang kota dan bangunan bertemu, untuk lebih spesifik, street wall merupakan lantai dasar pada sebuah bangunan. Street Wall merupakan sisi tepi dari sebuah kota yang mendefinisikan ruang kota. Sebuah ruang yang tidak memiliki sisi tepi atau yang memiliki sisi tepi namun dapat terbilang lemah, memiliki kecenderungan untuk kehilangan kualitas fungsinya bila dibandingkan dengan ruang yang memiliki sisi tepi. Hal ini dikarenakan sebuah tepian kota memunculkan kesan aman, nyaman, dan tertata/teratur dari ruang yang ada tersebut. Pada tepian kota, perbedaan antara kepemilikan ruang privat dan publik pun lebih terdefinisikan.

Tepian kota sebagai zona peralihan merupakan perbatasan antara ruang dalam dan ruang luar, tempat seseorang berpindah keluar dan masuk bangunan. Pada kawasan pusat kota maupun sekitarnya, tepian kota merupakan elemen yang tidak dapat dihindari keberadaannya. Tepian kota sebagai zona peralihan menyediakan peluang bagi kehidupan di dalam bangunan untuk berinteraksi dengan kehidupan kota. Oleh karena itu, tepian kota memiliki pengaruh 
yang cukup signifikan dalam menentukan kehidupan pada ruang kota yang berhubungan langsung dengannya.
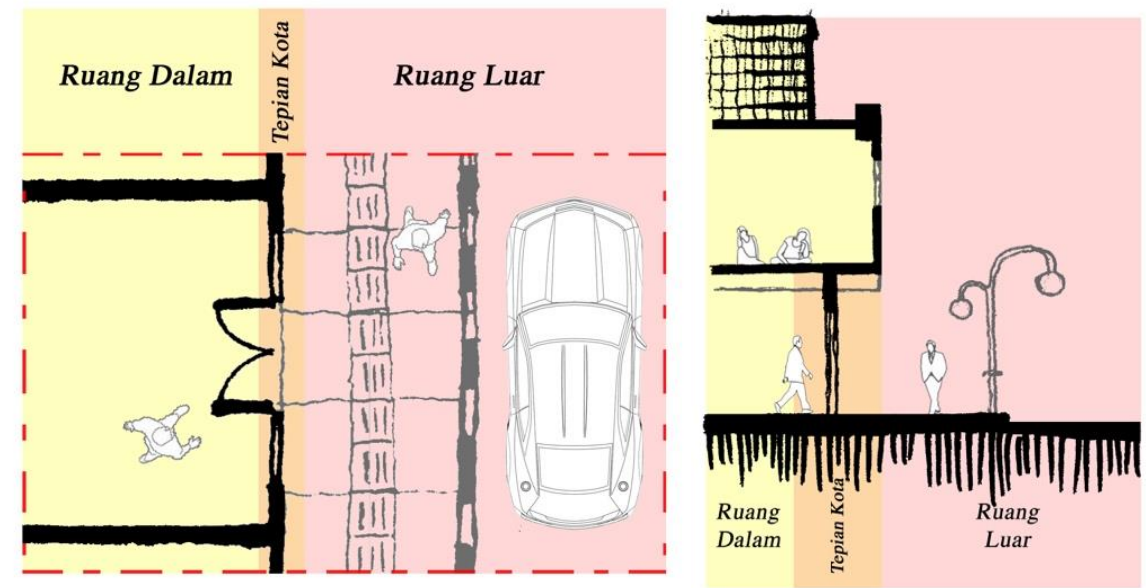

Gambar: Ruang Dalam, Ruang Luar, dan Tepian Kota

Sumber: Ilustrasi Pribadi

Pengalaman seseorang saat berjalan kaki menjadi penentu apakah sebuah perjalanan dapat dinikmati atau tidak. Semakin banyak aktivitas yang dapat dilakukan saat sedang berjalan, maka perjalanan pun menjadi lebih menarik. Terdapat beberapa hal yang dapat meningkatkan kualitas perjalanan, antar lain, lebar kaveling yang sempit, banyak bukaan yang dilewati, juga dapat berupa bantuan secara visual untuk meringankan perjalanan dengan menggunakan banyak garis/bentuk vertikal pada tepian kota. Untuk mempermudah pemahaman akan tepian kota yang dapat meningkatkan maupun menurunkan kualitas pengalaman perjalanan, tepian kota dikelompokkan menjadi 2 (dua) jenis, yaitu tepian kota yang lunak \& padat.

Menurut Edward T. White (1999), terdapat 3 jenis dari ruang publik yaitu: jalur setapak (path), portal, dan tempat (place). Frontage kota dapat masuk ke dalam kategori sebuah tempat sebagai ruang publik (place), di mana pada frontage kota pada dasarnya adalah sebuah plaza linear dengan berbagai destinasi di dalamnya. Pada frontage kota seseorang memiliki tempat untuk didatangi dan berpartisipasi dalam kehidupan perkotaan.
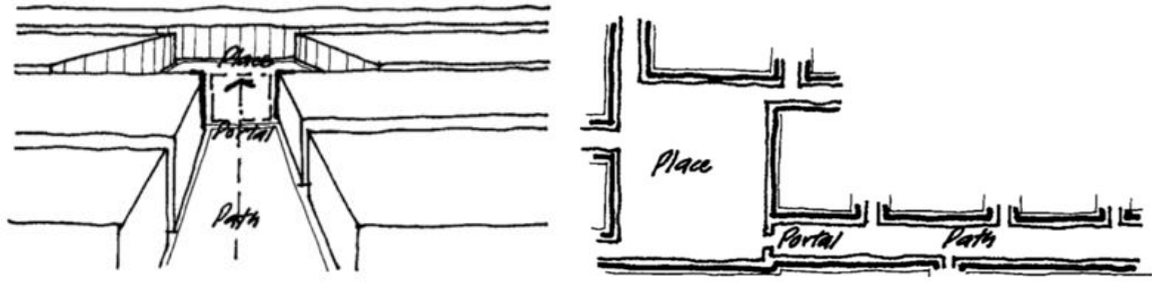

Gambar: Perbedaan Path, Portal, dan Path

(Sumber: Path, Portal, Place: Appreciating Public Space in Urban Environments oleh Edward T. White, 1999)

\subsection{ACTIVE FRONTAGE}

Untuk memaksimalkan pengalaman pengguna ruang publik, akan lebih baik bila ruang publik tersebut tertata dan terancang dengan mendetail dan baik. Sebuah ruang kota yang baik tentunya antar bangunan dan ruang terbukanya memiliki sosok yang sesuai satu sama lain. Di 
saat ada harmoni antar bangunan dan ruang publik sekitarnya, penggunaan ruang publik pun akan lebih menyenangkan.

Dalam buku Urban Design Compendium edisi 1, Llewelyn-Davies menyatakan bahwa ketertarikan terhadap arsitektur perkotaan/'urban architecture' meliputi bangunan dan ruang terbuka sebagai keseluruhan. Dilihat dari perspektif arsitektur perkotaan, keberhasilan sebuah bangunan ditentukan oleh kemampuannya untuk memberikan kontribusi positif kepada publik. Bagaimana bangunan menghadapi jalanan, menghidupkannya, dan memastikan bagaimana semua ruang terbuka di sekitar bangunan digunakan sebagai ruang positif. Tepian kota antara bangunan dan domain publik-lah yang menentukan hubungan antara ruang dalam dan ruang luar, ruang yang terbangun dan terbuka, publik dan pribadi, individu, dan masyarakat.

Sebagai bagian dari kawasan, tentunya elemen pelingkup memberi pengaruh kepada kehidupan di sekitarnya. Dalam buku "Urban Design Compendium" Llewelyn-Davies menyatakan bahwa tepian kawasan merupakan tempat terjadinya interaksi antara bangunan dan domain publik. Tempat yang memiliki detail yang indah tentunya akan memberikan rangsangan dan menyenangkan bagi yang menggunakan atau hanya sekedar melewatinya. Saat bangunan dan ruang terbuka cocok satu sama lain, sebuah bagian depan (fasad muka) yang aktif-pun akan tercapai. Fasad muka dapat dinilai aktif atau tidak berdasarkan frekuensi pintu dan jendela, irama vertikal bangunan, artikulasi hingga fasad bangunan, dan dapat melihat kebagian kehidupan dalam bangunan.

The Activity Center Design Guide mendefinisikan muka bangunan yang aktif/active frontage sebagai "Bagian depan depan jalan di mana terjadi pertemuan visual yang aktif antara mereka yang ada di jalanan, dan mereka yang ada pada lantai dasar bangunan. Kualitas ini meliputi di mana fasad depan bangunan, termasuk pintu masuk utama, menghadap dan terbuka menuju jalan". Muka bangunan yang aktif sering dianggap sebagai deretan deretan toko dengan kaca yang sangat banyak dan juga yang memiliki akses masuk ke dalamnya dan kafe yang sering 'tumpah' ke jalan.

Rancangan tepian kota yang aktif terhadap jalan akan meningkatkan ketertarikan publik terhadap bagian depan tepian tersebut, juga kehidupan pada bagian depan tepian tersebut. Kota Copenhagen melakukan penelitian mengenai rentang waktu aktivitas pada bagian depan bangunan dengan tepian kota/muka bangunan yang aktif dan pasif di tahun 2003. Dari penelitian tersebut dapat ditarik kesimpulan bahwa kehidupan pada bagian depan bangunan dengan muka aktif lebih tinggi hingga 7 (tujuh) kali lipat dibandingkan dengan bangunan dengan muka yang pasif.

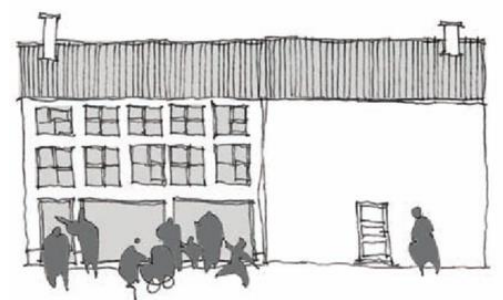

Gambar: Kehidupan Kota Pada Muka Bangunan Aktif Dibandingkan Dengan Tidak Aktif

Sumber: Cities for People, Jan Gehl

Sebuah frontage dianggap aktif bila memiliki jumlah pintu dan jendela yang lebih banyak dibandingkan dengan dinding kosong, frontage bangunan yang sempit, menimbulkan irama vertikal pada jalanan, adanya artikulasi pada fasad seperti adanya beranda untuk menyediakan perasaan terundang, juga penggunaan internal bangunan agar terlihat hidup dari luar bangunan, akan lebih baik bila kegiatan dalam bangunan 'tumpah' keluar bangunan. 


\section{METODA PENELITIAN}

Dalam Urban Design Compendium yang diadaptasi dari Gehl, 1994 dikatakan bahwa dalam mengamati frontage sebuah kawasan yang besar, akan lebih mudah bila dilakukan pembagian menjadi beberapa segmen. Masing-masing segmen tersebut, bila memungkinkan, dibagi dengan panjang masing-masing 100 meter. Berikut peta segmentasi pada kawasan penelitian Jl. Jend. Sundirman.

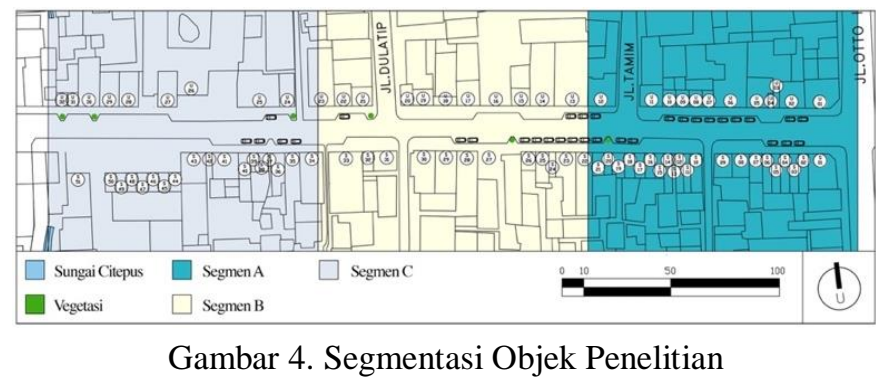

\section{ANALISA}

\subsection{IDENTIFIKASI AKTIVITAS KAWASAN}

Berdasarkan jenis-jenis aktivitas pada ruang publik yang dijelaskan oleh Jan Gehl, aktivitas pada kawasan dikelompokkan menjadi 3 (tiga) kelompok yaitu; Aktivitas Penting (Necessary Activities-NA), Aktivitas Pilihan (Optional Activites-OA), dan Aktivitas Sosial (Social Activities-SA). Berikut sampel proses identifikasi aktivitas pada Segmen A.

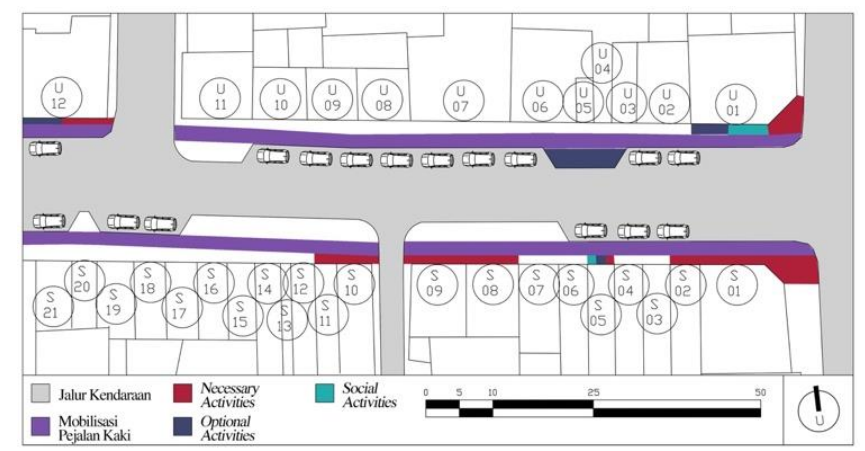

Gambar: Peta Aktivitas Jalur Pejalan Kaki Pada Segmen A 


\begin{tabular}{|c|c|l|}
\hline No. & $\begin{array}{c}\text { Jenis } \\
\text { Aktivitas }\end{array}$ & \multicolumn{1}{|c|}{ Aktivitas } \\
\hline U-01 & NA & Bekerja \\
\cline { 2 - 3 } & OA & Bersantai (duduk) \\
\cline { 2 - 3 } & SA & Berbincang \\
\hline U-04 & OA & Bersantai (duduk) \\
\hline U-12 & NA & Berjualan \\
\cline { 2 - 3 } & OA & Membeli jajanan \\
\hline
\end{tabular}

\begin{tabular}{|c|c|l|}
\hline No. & $\begin{array}{c}\text { Jenis } \\
\text { Aktivitas }\end{array}$ & \multicolumn{1}{|c|}{ Aktivitas } \\
\hline S-01 & NA & Berjualan \\
\cline { 3 - 3 } & & Bekerja \\
\hline S-02 & NA & $\begin{array}{l}\text { Menunggu } \\
\text { kendaraan umum }\end{array}$ \\
\hline S-05 & NA & Bekerja \\
\cline { 3 - 3 } & OA & Bersantai (duduk) \\
\cline { 3 - 3 } & SA & Berbincang \\
\hline S-08 & NA & Berjualan \\
\hline S-09 & NA & Berjualan \\
\hline S-10 & NA & Berjualan \\
\hline S-11 & NA & Berjualan \\
\hline
\end{tabular}

Tabel: Aktivitas Jalur Pejalan Kaki Pada Segmen A

Aktivitas Ruang Luar pada jalur pedestrian Segmen A meliputi ketiga jenis aktivitas yang ada necessary activities (NA), optional activites (OA), dan social activities (SA). Jenis aktivitas yang terjadi pada bagian depan bangunan bervariasi dari tidak ada aktivitas hingga terdapat 3 jenis aktivitas pada bagian depan bangunan. Aktivitas yang ada beragam mulai dari bekerja, berdagang, bersantai hingga berbincang.

Aktivitas yang ada pada segmen A tersebar pada 13 dari 33 bagian depan bangunan, dengan kata lain aktivitas pada bagian depan bangunan mencapai 39.39\% dari total bangunan yang ada. Sedangkan perluasan jalur pejalan kaki yang memiliki aktivitas di dalamnya terdapat 1 dari 4 perluasan, dengan kata lain aktivitas pada perluasan jalur pejalan kaki mencapai $25 \%$ dari total perluasan yang ada.

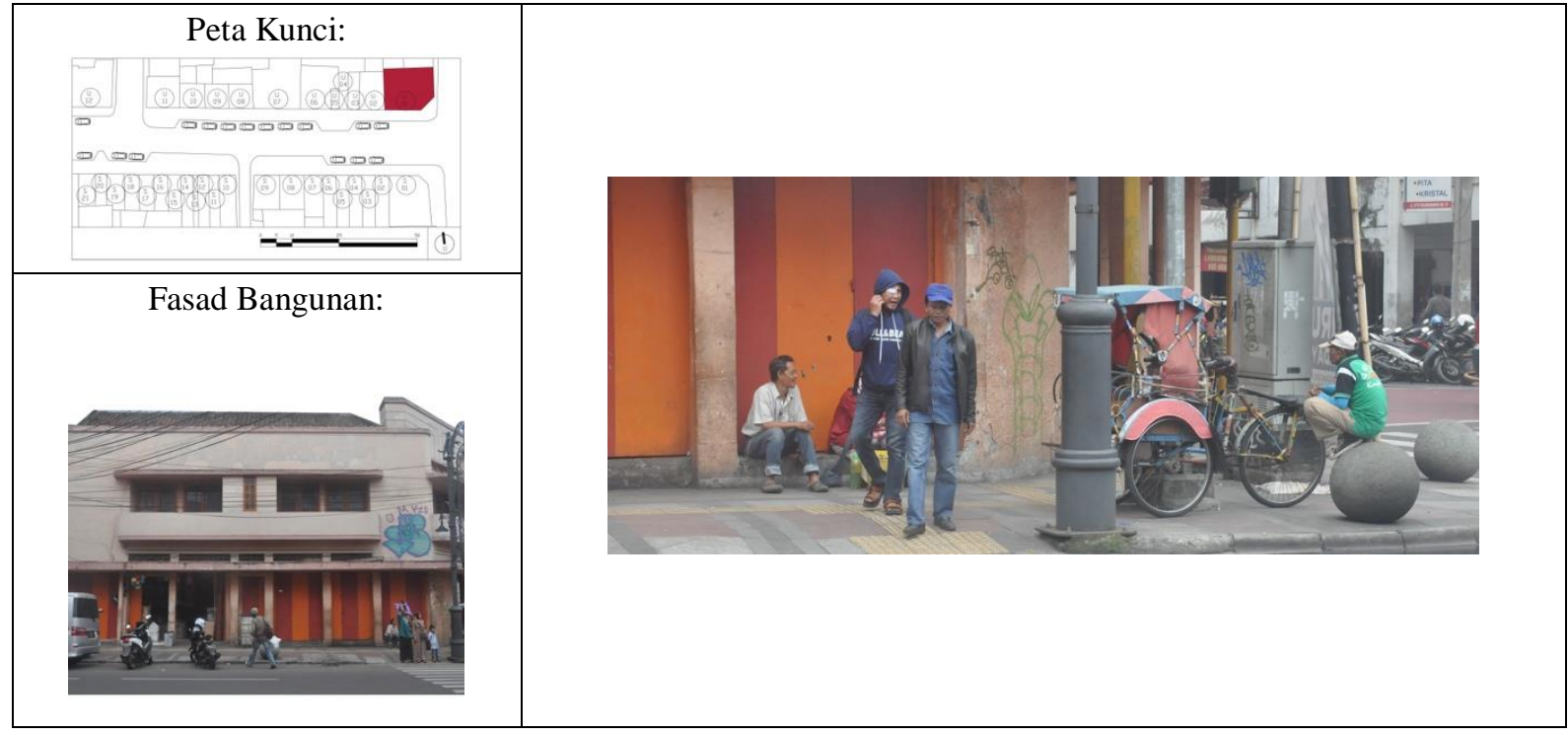

Gambar: Contoh Aktivitas Pada Segmen A (Bangunan U-01)

Pada titik ini pengguna ruang publik yang melakukan jenis aktivitas necessary activites merupakan tukang becak, di mana lokasi titik yang berada pada hoek jalan membuat tempat yang strategis untuk mencari pelanggan. Selain tukang becak, pengguna ruang publik yang melakukan jenis aktivitas yang sama merupakan pejalan kaki yang sedang melakukan mobilisasi menuju tempat tujuan berikutnya. 
Pengguna ruang publik yang melakukan jenis aktivitas optional activities merupakan masyarakat yang bersantai pada pojokan (tonjolan pada fasad) yang memungkinkan bagi pengguna untuk menetap. Dengan adanya tempat untuk menetap (good place for staying), pengguna ruang publik yang melakukan jenis aktivitas optional activities pun melakukan social activities.

\subsection{IDENTIFIKASI FUNGSI BANGUNAN}

Pada identifikasi fungsi bangunan, digunakan pengelompokkan berdasarkan fungsi yang ada pada Rencana Tata Ruang Wilayah. Dikarenakan fungsi kawasan merupakan fungsi komersil, presentase bangunan non-komersil pada kawasan akan diperhitungkan untuk nantinya dilihat apakah memiliki pengaruh terhadap kawasan atau tidak. Setelah masingmasing segmen di identifikasi berdasarkan fungsi yang umum (seperti perdagangan, jasa, dan sebagainya), fungsi diidentifikasi dengan lebih khusus (seperti toko mainan, toko tekstil, dan sebagainya). Berikut sampel proses identifikasi fungsi pada Segmen A.

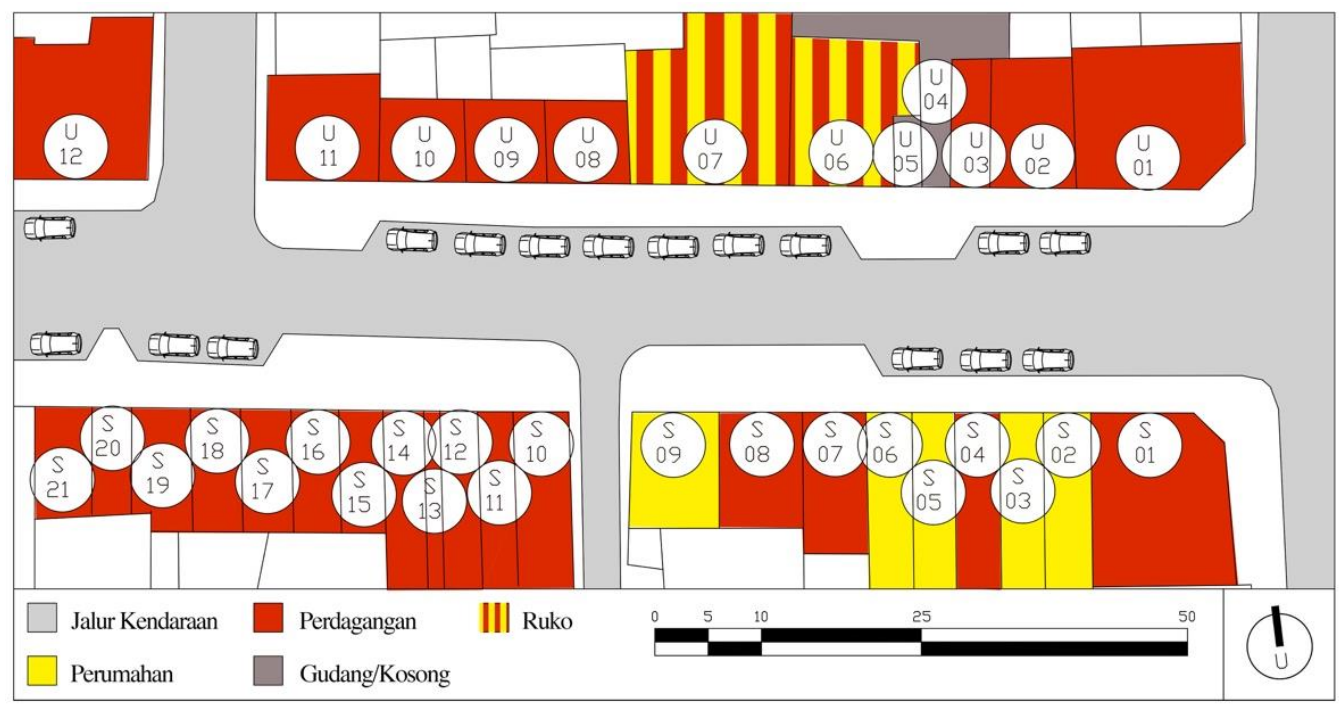

Gambar: Peta Fungsi Bangunan Pada Segmen A

Terdapat 4 jenis fungsi pada Segmen A yaitu perdagangan, perumahan, ruko, dan gudang/kosong. Bangunan komersil tidak sebatas pada toko saja, namun terdapat bangunan komersil lainnya yaitu rumah makan. Bangunan non komersil pada Segmen A berjumlah 7 bangunan dari 33 bangunan (21.21\%), di mana 2 dari 7 bangunan non-komersil memiliki fungsi gudang (6.06\%), dan 5 dari 33 bangunan non-komersil memiliki fungsi rumah tinggal $(15.15 \%)$.

Fungsi yang bersebelahan pada Segmen A dapat mendukung satu sama lain. Segmen A memiliki beberapa fungsi rumah tinggal dan ruko, lapis ke 2 maupun ke 3 bangunan pada daerah sekitar segmen ini pun merupakan perumahan. Fungsi seperti toko keperluan balita dan toko obat-obatan berada di lokasi yang tepat bila berdekatan dengan permukiman. Dengan berdekatannya fungsi-fungsi ini, penghuni pada rumah tinggal tidak perlu berjalan terlalu jauh untuk memenuhi kebutuhan sehari-harinya.

\subsection{IDENTIFIKASI FRONTAGE BANGUNAN}

Frontage bangunan diidentifikasi berdasarkan aspek sifat (masif/ringan), material bukaan, besar bukaan, akses visual kedalam bangunan, dan durasi bukaan terbuka. Sifat masif atau ringan bangunan dapat dilihat dari banyaknya garis horizontal maupun vertikal pada fasad 
bangunan, semakin didominasi oleh garis horizontal bangunan akan masif/berat, semakin didominasi oleh garis vertikal bangunan akan ringan. Berikut sampel proses identifikasi frontage pada Segmen A.

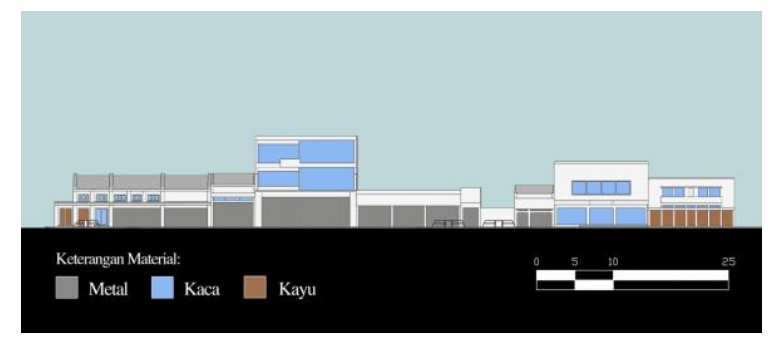

Gambar: Frontage Bangunan Pada Segmen A Utara

Sifat mayoritas pada Segmen A Utara adalah kesan ringan, di mana 3 dari 12 bangunan memiliki kesan masif/berat, dan 9 dari 12 bangunan memiliki kesan ringan. Besar bukaan mayoritas 76-100\%. Jenis bukaan mayoritas adalah pintu metal, di mana 8 dari 12 bangunan memiliki pintu metal, 2 dari 12 memiliki pintu kaca, dan 2 dari 12 memiliki pintu kayu.

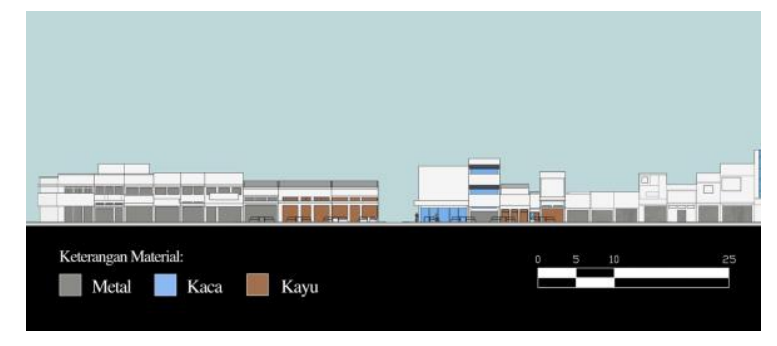

Gambar: Frontage Bangunan Pada Segmen A Selatan

Sifat mayoritas pada Segmen A Selatan adalah kesan berat, di mana 17 dari 21 bangunan memiliki kesan masif/berat, dan 4 dari 21 bangunan memiliki kesan ringan. Besar bukaan mayoritas 76-100\%. Jenis bukaan mayoritas adalah pintu metal, di mana 15 dari 21 bangunan memiliki pintu metal, 1 dari 21 memiliki pintu kaca, dan 5 dari 21 memiliki pintu kayu.

\subsection{IDENTIFIKASI KUALITAS RUANG PUBLIK (STREET FURNITURE)}

Kualitas ruang publik dinilai berdasarkan 12 aspek kualitas ruang publik Jan Gehl dalam buku Cities for People, seperti proteksi, kenyamanan, skala, dan sebagainya. Oleh karena itu dibutuhkan pemetaan street furniture untuk melihat ruang yang terbentuk. Berdasarkan data yang ada, jarak antar lampu jalan memungkinkan ada daerah yang gelap. Hal ini dapat mengakibatkan timbulnya rasa kurang aman saat malam hari. Selain itu, tidak terdapat perlindungan dari polusi, debu, dan bising bagi pejalan kaki.

Pada aspek kenyamanan, terdapat ruang untuk berjalan dengan permukaan yang nyaman untuk digunakan berjalan (tidak licin). Selain itu, terdapat edge effect, di mana pengguna ruang publik akan berdiam pada bagian depan bangunan, namun hal ini membuat beberapa perluasan jalur pedestrian kosong. Terdapat tempat duduk, namun bising kendaraan membuat kurang nyaman untuk bersosialisasi.

\subsection{TITIK-TITIK PERSEBARAN AKTIVITAS RUANG LUAR}




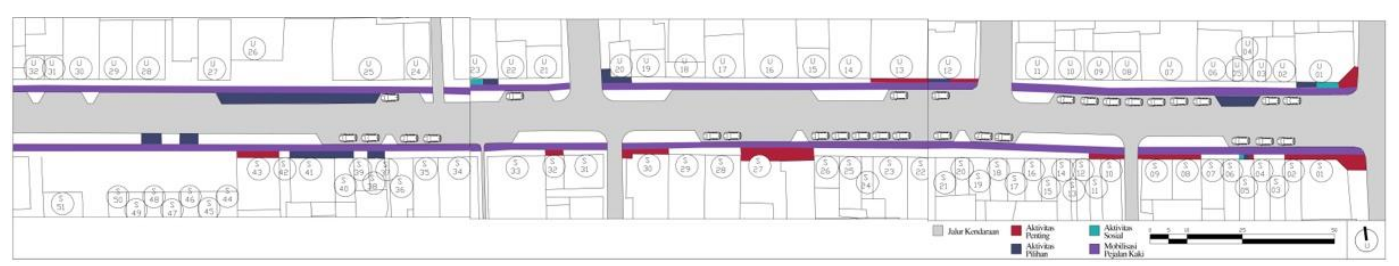

Gambar: Peta Persebaran Aktivitas Kawasan

Aktivitas ruang luar pada kawasan objek penelitian didominasi oleh jenis necessary activities, diikuti oleh optional activites, dan yang paling sedikit dilakukan pada ruang luar kawasan ini yaitu social activities. Segmen A, B, dan C memiliki 3 jenis aktivitas. Segmen dengan bagian depan bangunan yang paling ramai oleh aktivitas ruang luar yaitu Segmen $\mathrm{C}$ (40.74\%), diikuti oleh Segmen A (39.39\%), dan terakhir yaitu Segmen B (26.8\%).

Penggunaan perluasan jalur pejalan kaki paling tinggi berada pada Segmen C (100\&), diikuti oleh Segmen A (25\%), dan terakhir yaitu Segmen B (0\%). Bila dibandingkan dengan perluasan jalur pejalan kaki pada Segmen A dan Segmen B, perluasan pada Segmen C ditempatkan pada bagian depan bangunan yang memiliki setback. Penempatan ini membentuk sebuah ruang yang menyerupai plaza kecil. Plaza kecil ini mengumpulkan konsentrasi orangorang dan dapat berfungsi sebagai simpul.

\subsection{HUBUNGAN ANTARA FUNGSI BANGUNAN DAN AKTIVITAS RUANG LUAR}

Secara garis besar, fungsi bangunan pada kawasan ini terdapat 5 ragam fungsi, yaitu perdagangan, permukiman, ruko, jasa/bank, dan gudang/kosong. Fungsi-fungsi tersebut terbagi di dalam tiga segmen penelitian dengan perbandingan 4:3:3 (A:B:C), di mana pada Segmen A terdapat 4 ragam fungsi, dan pada Segmen B juga Segmen $C$ terdapat 3 ragam fungsi. Berikut sampel proses analisis hubungan antara fungsi bangunan dan aktivitas ruang luar pada Segmen A.
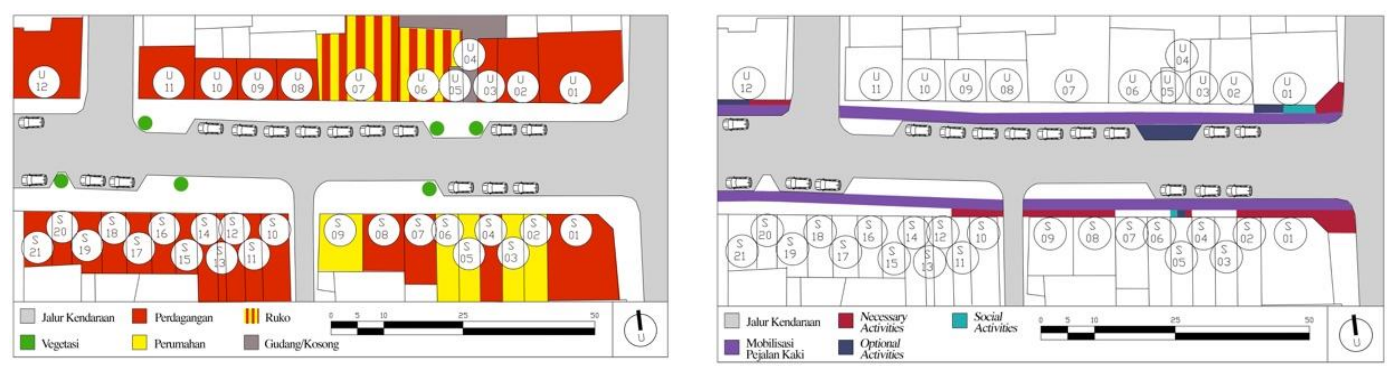


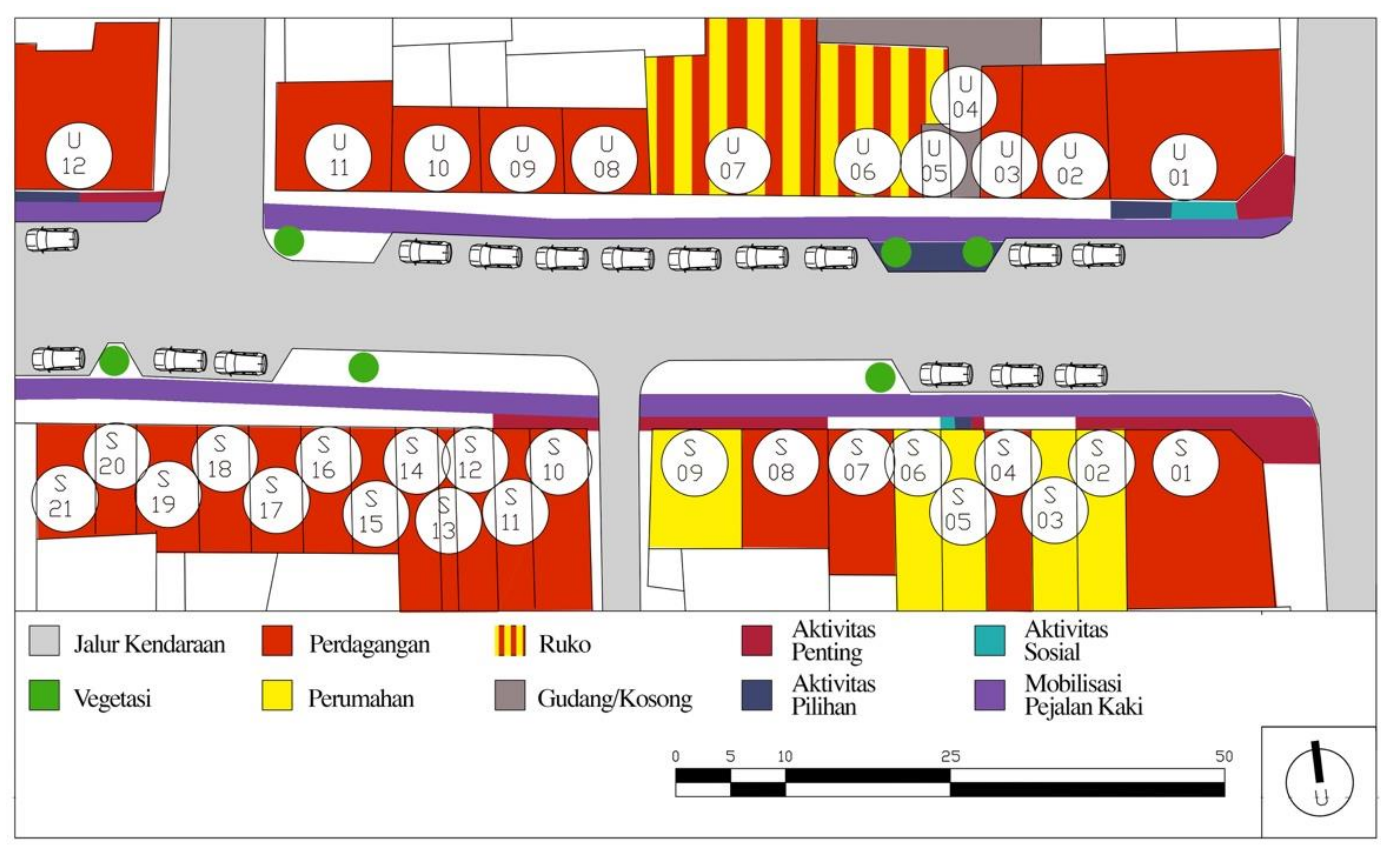

Gambar: Peta Hubungan Antara Fungsi Bangunan dan Aktivitas Ruang Luar Segmen A

Bila dilihat dari pemetaan pada Gambar 5.1, walaupun 2 (dua) bangunan memiliki fungsi yang sama bukan berarti aktivitas pada ruang luarnya pun akan sama. Bangunan dengan lokasi dan fungsi yang serupa seperti bangunan S-08 dan S-15 dapat memiliki aktivitas yang berbeda pula. Pada bagian depan bangunan S-08 pengguna ruang publik melakukan jenis kegiatan necessary activities namun statis pada bagian depan bangunan. Sedangkan pada bagian depan bangunan S-15 dengan fungsi dan keadaan sekitar yang serupa dengan S-08 tidak terjadi aktivitas yang memerlukan pengguna untuk menetap pada bagian depan bangunan.

\subsection{HUBUNGAN FRONTAGE DAN AKTIVITAS RUANG LUAR}

Pembahasan terbagi menjadi hubungan sifat frontage dan aktivitas ruang luar, dan hubungan kedalaman akses visual dan aktivitas ruang luar. Sifat frontage bangunan yang ada dilihat dari material bukaan bangunan dan garis dominan pada fasad bangunan. Material bukaan seperti metal dianggap menambah kesan berat, material kaca dianggap menambah kesan ringan, sedangkan material kayu berat atau ringannya dilihat dari bagaimana bentuk bukaan tersebut. Fasad dengan garis dominan horizontal dianggap memberi kesan berat, sedangkan fasad dengan garis dominan vertikal dianggap ringan. Berikut sampel proses analisis hubungan sifat frontage dan aktivitas ruang luar pada Segmen.
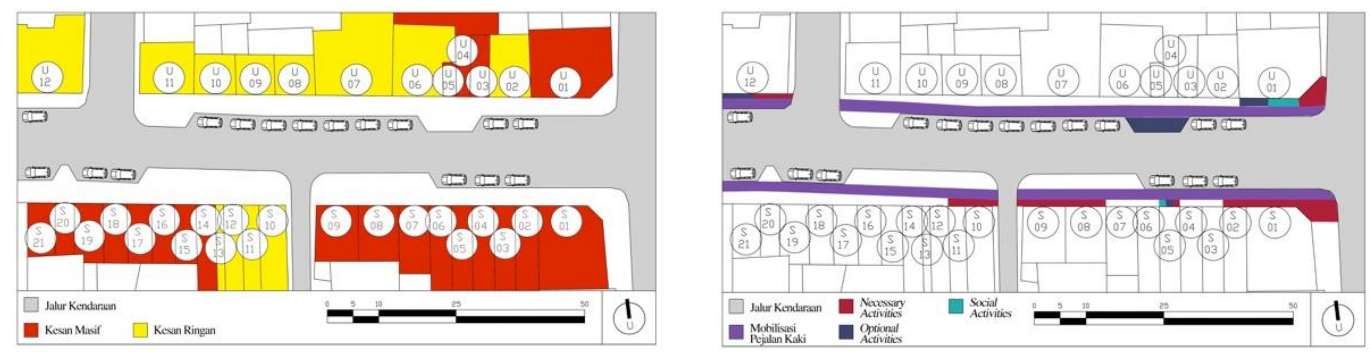


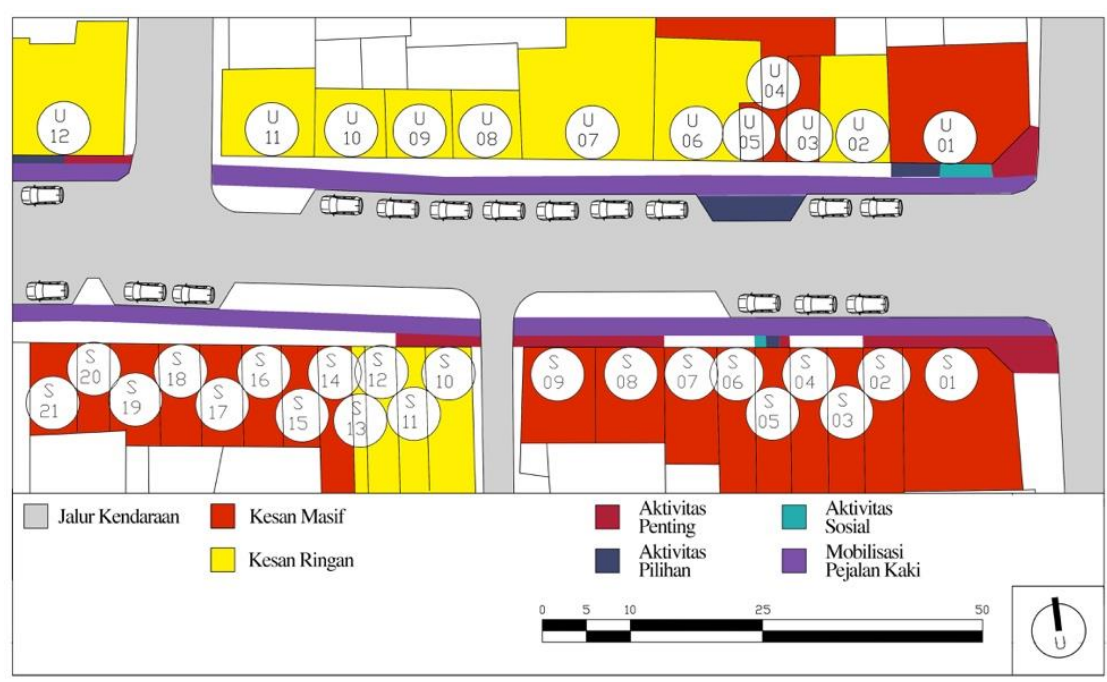

Gambar: Peta Hubungan Antara Sifat Frontage dan Aktivitas Ruang Luar Segmen A

Dari 9 bangunan dengan aktivitas pada ruang luarnya, 6 di antaranya berada pada bangunan dengan kesan masif/berat. Aktivitas yang berada pada bagian depan bangunan dengan kesan ringan meliputi dua jenis aktivitas necessary activities dan optional activities, sedangkan pada bangunan masif terdapat ketiga jenis aktivitas ruang luar, termasuk social activities.

Perbedaan aktivitas ruang luar bangunan dengan kesan masif dan ringan pada Segmen A yaitu bila pada bangunan dengan kesan ringan penggunanya merupakan pedagang kaki lima (gambar 5.14), sedangkan pada bangunan dengan kesan ringan penggunanya merupakan masyarakat yang menunggu kendaraan umum (gambar 5.13). Dari pemetaan Hubungan Antara Sifat Frontage dan Aktivitas Ruang Luar Segmen A juga dapat dilihat bahwa pengguna lebih banyak beraktivitas sosial pada bangunan dengan kesan masif/berat.

Pada objek penelitian yang merupakan kawasan perdagangan, akses visual kedalam bangunan menjadi aspek yang sangat penting. Dengan adanya akses visual ke dalam bangunan, pejalan kaki yang sedang melewati jajaran pertokoan dapat melihat barang yang dijual oleh toko tersebut, dan bila tertarik akan menghampiri toko tersebut. Akses visual ke dalam bangunan memiliki peranan yang cukup besar dalam menentukan apakah bangunan dapat mengundang atau tidak. Berikut sampel proses analisis hubungan kedalaman akses visual dan aktivitas ruang luar pada Segmen.
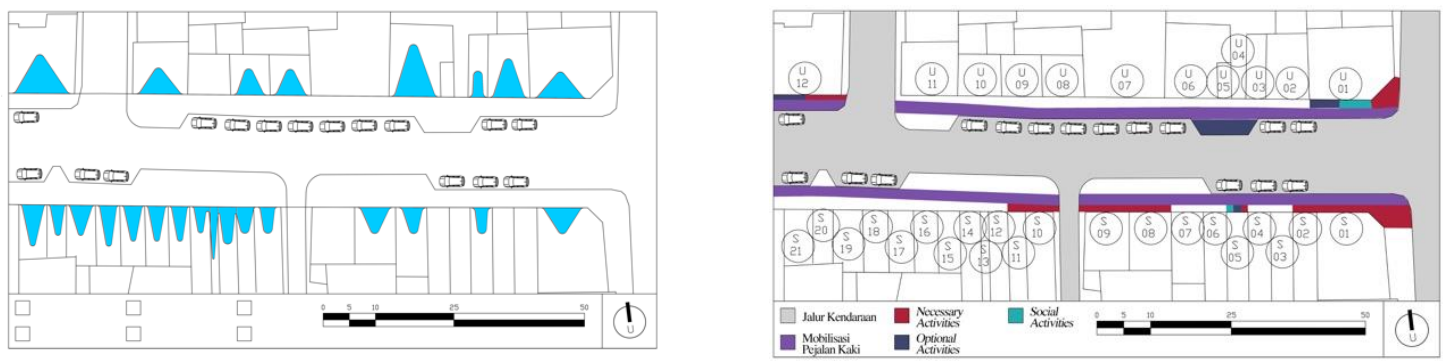


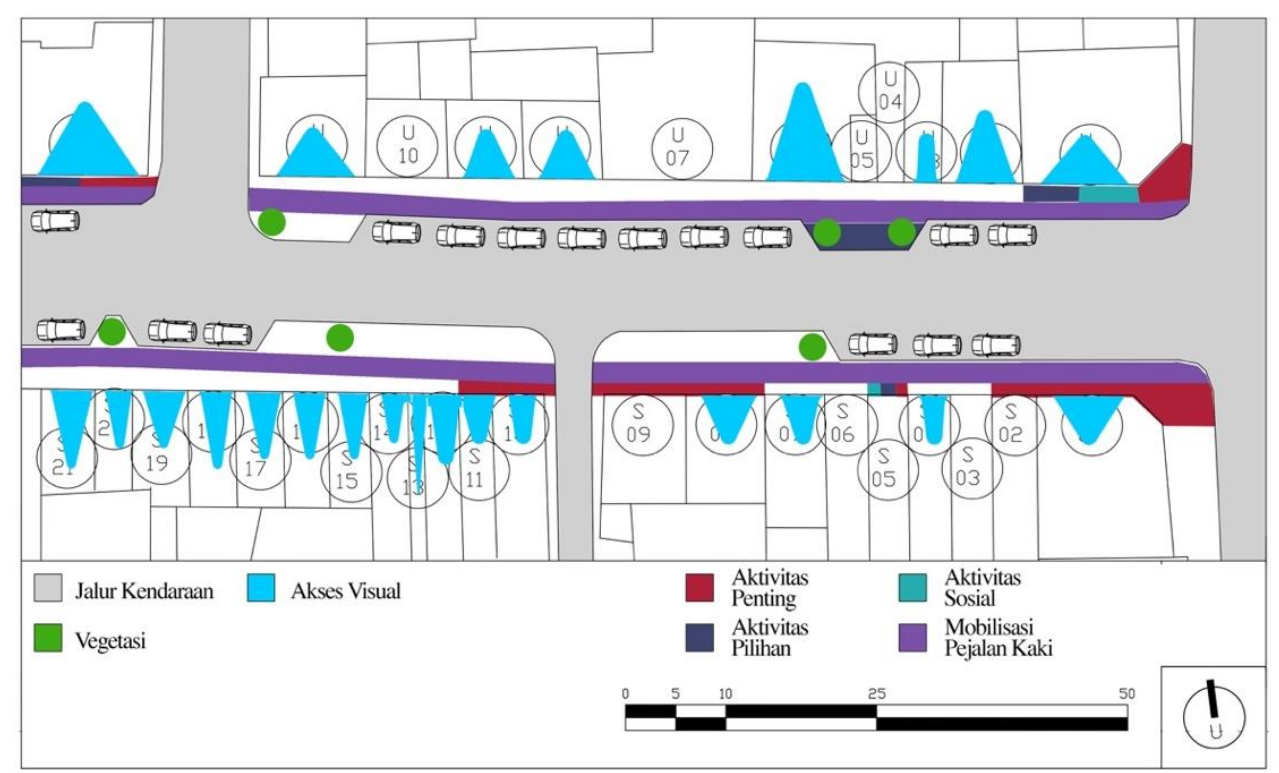

Gambar. Peta Hubungan Antara Kedalaman Akses Visual Bangunan dan Aktivitas Ruang Luar Segmen A

Kedalaman akses visual ke dalam bangunan pada objek penelitian beragam dari tidak ada kedalaman sama sekali, kedalaman 5 meter, hingga kedalaman 30 meter. Untuk memudahkan pembahasan, akses visual kedalam bangunan dikelompokkan dalam 3 (tiga) kategori yaitu, tidak ada akses visual, akses visual dangkal (1-5 meter), akses visual sedang (610 meter), dan akses visual dalam (11-30 meter).

Pada Segmen A, kebanyakan pengguna ruang publik berkegiatan pada bagian depan bangunan yang memiliki kedalaman akses visual yang dangkal, sedang dan tanpa adanya akses visual. Namun jenis aktivitas terbanyak ada pada bangunan U-01 dengan 3 jenis aktivitas, dan S-05 dengan 3 jenis aktivitas. Bangunan U-01 dengan kedalaman akses yang dangkal, pengguna ruang publiknya beraktivitas pada bagian bukaan yang tertutup. Namun tidak berada terlalu jauh dari bukaan dengan akses visual ke dalam bangunan. Keberadaan dinding masif pada U-01 dan S-05 memutus konektivitas antar ruang luar dan ruang dalam. Oleh karena itu, pengguna membentuk ruangnya sendiri.

\subsection{TIPOLOGI RUANG}

Rob Krier menyatakan bahwa bermacam-macam tipe bangunan yang memiliki fasad dengan kesesuaian fungsi dan metode konstruksi akan memengaruhi ruang sebuah kota. Ruang-ruang positif dan negatif tercipta dari susunan massa muka bangunan. Sebuah ruang kota yang fisiknya terencana dengan baik (terutama potongan bangunannya), dapat mengundang maupun menolak kontak antar ruang luar dan ruang dalam dalam hal penglihatan maupun pendengaran.

Seperti yang sudah dibahas pada sub-bab sebelumnya bahwa sebuah aktivitas pada ruang luar tidak dapat semata-mata dipengaruhi oleh sifat frontage (masif/ringan) maupun akses visual ke dalam bangunan saja, ada faktor lain yang memengaruhi persebaran aktivitas pada ruang luar. Dalam penilaian hubungan antara aktivitas ruang luar dan frontage bangunan dibutuhkan faktor lainnya, yaitu ruang yang terbentuk dari pertemuan antara beragam jenis frontage dan ruang pada jalur pejalan kaki.

Pada objek penelitian, ruang-ruang yang terbentuk dari pertemuan ragam frontage dan ruang pada jalur pejalan kaki dapat ditipologikan menjadi 4 (empat) jenis. Pertama, tipologi ruang dengan setback. Setback sebuah bangunan saat dipertemukan dengan jalur pejalan kaki dapat menciptakan sebuah plaza kecil yang berfungsi sebagai simpul. 


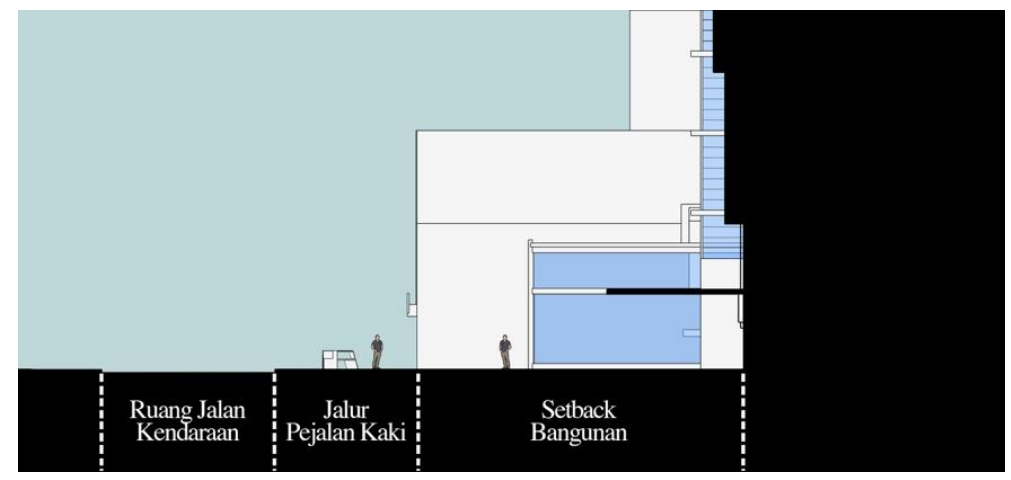

Gambar: Potongan Tipologi Ruang Setback (U-26)

Kedua, tipologi ruang dengan arkade. Tipologi ini serupa dengan tipologi ruang setback, di mana jalur pejalan kaki bertemu dengan ruang pada bagian depan bangunan yang dibuat lebih mundur dari lingkungan sekitarnya. Namun, pada tipologi arkade ruang yang tercipta memiliki bidang atas yang tertutup secara penuh dan terdapat elemen garis vertikal berupa kolom yang menopang lantai atasnya. Bidang atas ini memberi perlindungan yang lebih kepada pengguna ruang dari cuaca, perlindungan yang tersedia ini menambahkan kenyamanan pada frontage bangunan dengan tipe arkade.

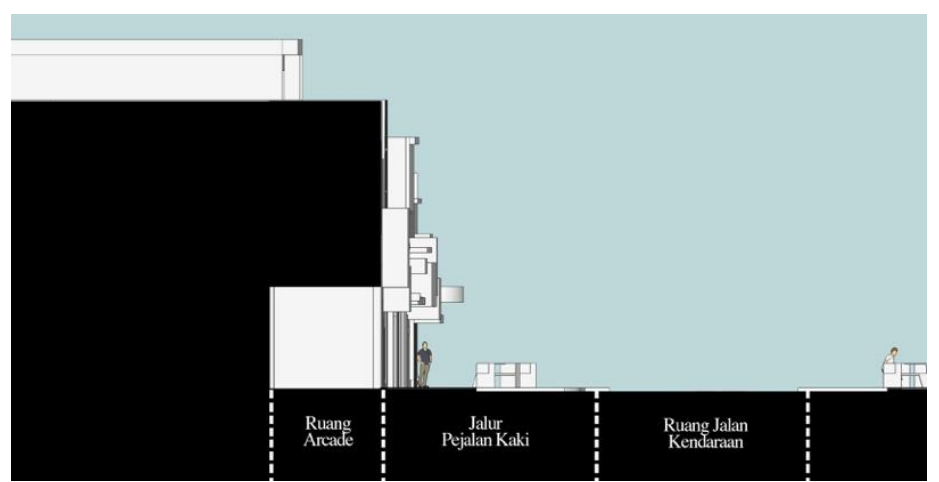

Gambar: Potongan Tipologi Ruang Arcade (U-16)

Ketiga, tipologi ruang tanpa setback. Tipe ruang tanpa setback ini merupakan tipe yang paling mudah di temukan pada objek penelitian. Tipe ruang ini tercipta dikarenakan objek penelitian berada pada kawasan dengan garis sempadan nol, di mana dinding bangunan dibuat rapat dengan jalur pejalan kaki. Bangunan dengan tipe ruang tanpa setback ini hanya menawarkan perlindungan bagi pengguna ruang luar sebatas pada tritis pada bagian depan bangunan.

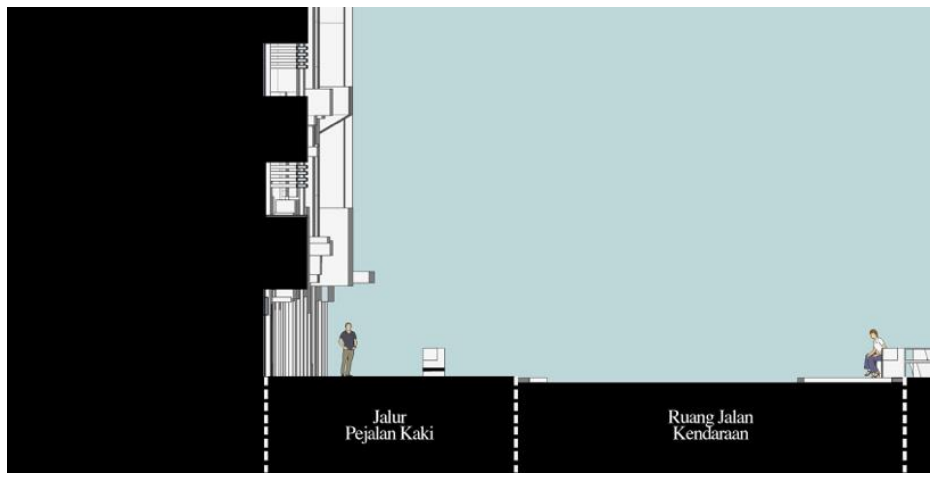


Keempat, tipologi ruang pada hoek jalan. Karakter ruang ini serupa dengan karakter ruang tanpa setback, yang membedakan antar keduanya ialah lokasi bangunan dengan tipologi ruang pada hoek jalan ini berada pada pertemuan dua atau lebih ruas jalan. Dengan lokasi bangunan yang berada pada hoek jalan, lebih banyak kemungkinan aktivitas yang dapat terjadi di dalamnya.

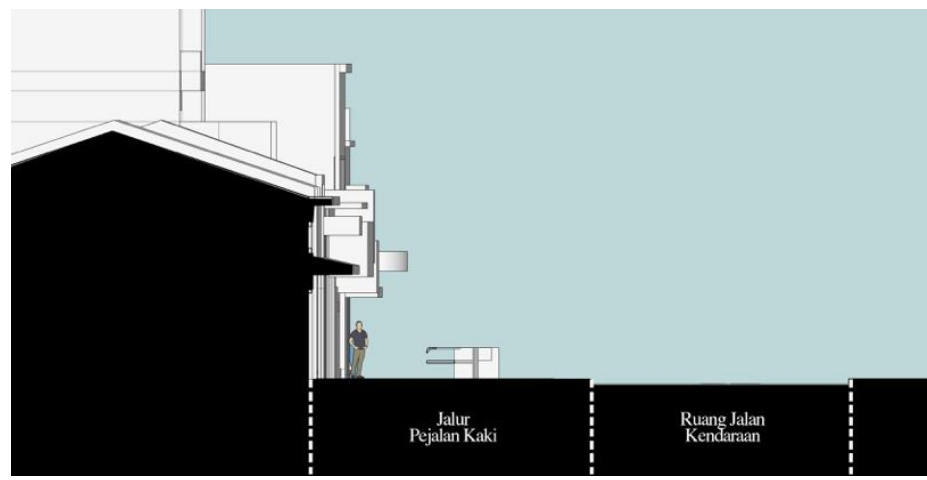

Gambar Potongan Tipologi Ruang Pada Hoek (S-11) Segmen B.

Berikut sampel proses analisis hubungan tipologi ruang dan aktivitas ruang luar pada
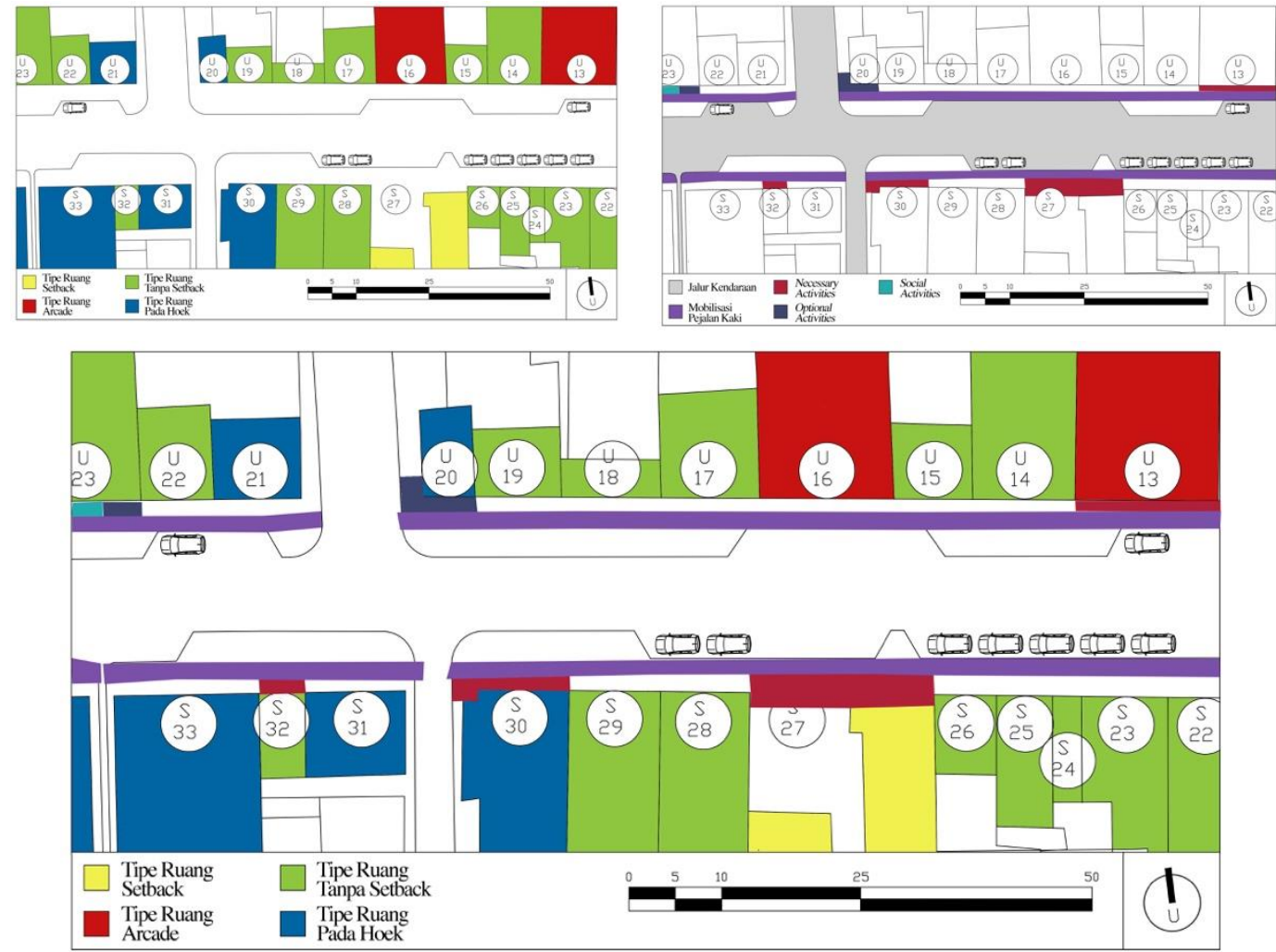

Gambar Peta Hubungan Antara Tipologi Ruang dan Aktivitas Ruang Luar Segmen B

Segmen B memiliki variasi tipologi ruang yang paling lebgkap bila dibandingkan dengan segmen lainnya. Namun, kondisi ruang yang beragam ini bukan berarti Segmen B akan 
memiliki tingkat aktivitas yang tinggi. Pada kenyataannya, Segmen B memiliki tingkat aktivitas paling rendah bila dibandingkan dengan segmen lainnya. Hal ini dapat terjadi dikarenakan tidak ada bentuk ruang yang konsisten pada kawasan membuat pengguna tidak nyaman dan bingung saat akan menentukan di mana mereka harus memilih titik untuk beraktivitas. Bukan hanya optional activities maupun social activities saja, bahkan pedagang kaki lima yang melakukan necessary activities pun kebingungan saat harus memilih titik untuk beraktivitas. Padahal bila dilihat dari segi fungsi, kawasan ini dapat terbilang menguntungkan bagi pedagang kaki lima dikarenakan kawasan ini dikelilingi oleh kantor.

\section{KESIMPULAN}

Aktivitas pada kawasan tersebar dengan cukup merata. Tingkat persebaran aktivitas tertinggi berada pada segmen c, diikuti oleh segmen a, dan aktivitas paling rendah berada pada segmen b. Segmen c dapat dikatakan sebagai segmen dengan tingkat aktivitas tertinggi dikarenakan keberadaan simpul aktivitas pada bagian utara dan bagian selatan kawasan. Keberadaan simpul ini memiliki peranan yang tinggi pada kawasan dengan fungsi utama komersil. Simpul dapat menarik pengunjung untuk datang kepada titik tersebut, dan berlamalama pada titik tersebut. Dikarenakan sifatnya yang menarik perhatian pengunjung untuk berkegiatan pada titik tersebut, simpul ini mewadahi jenis aktivitas optional activities dan social activities.

Populasi jenis aktivitas necessary activities paling tinggi berada pada segmen B. Hal ini dikarenakan kebanyakan dari pelaku necessary activities adalah pedagang kaki lima. Pedagang kaki lima menargetkan tempat-tempat potensial seperti di sekitar bank, agar karyawan dapat membeli makan siang yang dijualnya.

Selain terkonsentrasi pada simpul, jenis aktivitas optional activities dan social activities juga seringkali ditemukan pada daerah hoek jalan di mana pengunjung dapat menemukan tempat untuk menepi dan berdiam pada titik tersebut. Hal ini dikarenakan pada persimpangan jalan, pengguna ruang luar dapat menikmati kehidupan kota.

Simpul-simpul yang ada dan hoek jalan dapat dikatakan sebagai good place for staying. Hal ini dikarenakan pada tempat tempat tersebut, pengguna ruang luar memiliki kesempatan untuk berjalan, duduk, berdiri dan menetap, melihat-lihat baik itu ke dalam bangunan maupun melihat lingkungan kota, pengguna dapat berbincang satusama lain.

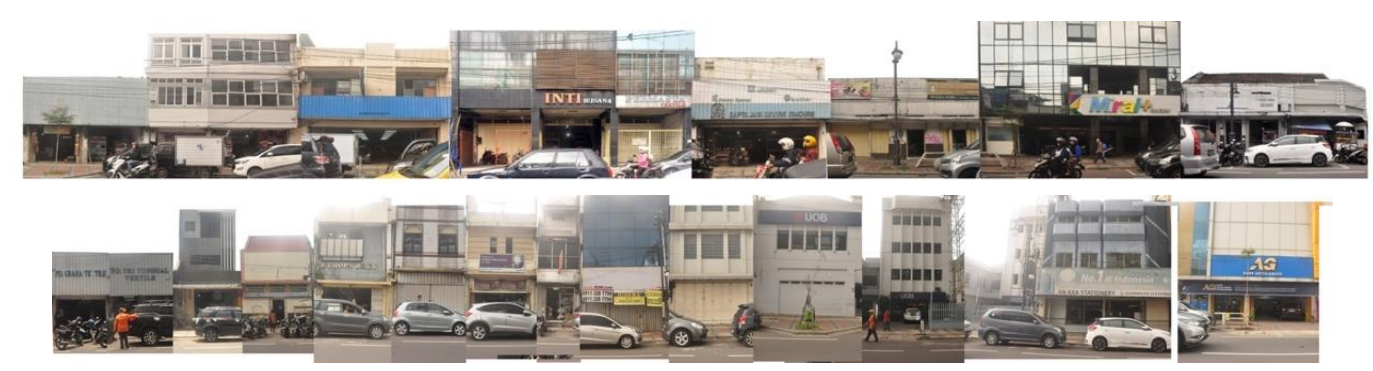

Gambar: Contoh Ragam Frontage

Frontage pada kawasan cukup beragam. Hal ini dianggap cukup baik dalam mengundang pengunjung. Rata-rata bukaan pada frontage bangunan melebihi 50\% dari luas dinding lantai dasar tersebut. Namun, waktu bukaan tersebut dapat diakses terbilang kurang maksimal karena kebanyakan dari toko hanya bukxa saat siang hari dan hari kerja. Oleh karena itu, pada malam hari frontage bangunan menjadi sangat pasif.

Kemampuan bagi kawasan untuk dapat mengundang atau malah menolak pengunjung dapat dilihat dari kecepatan pengguna ruang publiknya berjalan. Pengguna ruang publik pada 
kawasan ini berjalan dengan santai, hal ini mengindikasi bahwa kawasan ini merupakan kawasan yang mengundang bagi pengunjung. Ciri lain dari kawasan yang mengundang dapat ditemukan pada kawasan ini, seperti disaat toko terbuka, hanya sedikit dinding yang memisahkan antara ruang luar dan ruang dalam dikarenakan rata rata bukaan memiliki besaran 76-100\% dari total luas dinding lantai dasar, lantai dasar yang menjadi atraksi utama bagi pejalan kaki dibuat memiliki ketinggian yang sama dengan jalur pejalan kaki, orientasi bangunan saling berhadapan menghadap sumbu jalan, dan jarak antar pejalan kaki saat berjalan berdekatan, namun ada ruang yang cukup untuk mempertahankan ruang personal (personal space).

Keadaan frontage tidak terlepas dari akses visual dari luar bangunan ke dalam bangunan. Bangunan dengan kedalaman akses yang dangkal, pengguna ruang publiknya beraktivitas pada bagian bukaan yang tertutup. Namun tidak berada terlalu jauh dari bukaan dengan akses visual ke dalam bangunan. Keberadaan dinding masif pada beberapa bangunan memutus konektivitas antar ruang luar dan ruang dalam. Oleh karena itu, pengguna membentuk ruangnya sendiri. Ruang yang dibentuk sendiri ini memanfaatkan frontage bangunan dengan akses visual yang dangkal maupun tanpa akses visual. Keadaan ini membuktikan bahwa, akses visual tidak menjadi pertimbangan satu-satunya bagi pengguna ruang luar untuk beraktivitas pada suatu tempat.

Rob Krier menyatakan bahwa bermacam-macam tipe bangunan yang memiliki fasad dengan kesesuaian fungsi dan metode konstruksi akan memengaruhi ruang sebuah kota. Ruang-ruang positif dan negatif tercipta dari susunan massa muka bangunan. Sebuah Ruang kota yang fisiknya terencana dengan baik (terutama potongan bangunannya), dapat mengundang maupun menolak kontak antar ruang luar dan ruang dalam dalam hal penglihatan maupun pendengaran. Maka dari itu ditemukan tipologi ruang yang terbentuk oleh pertemuan ragam frontage dan ruang pada jalur pejalan kaki. Ruang yang tercipta ini dapat ditipologikan menjadi 4 (empat) jenis tipologi ruang dengan setback, tipologi ruang dengan arkade, tipologi ruang tanpa setback, dan tipologi ruang pada hoek jalan.

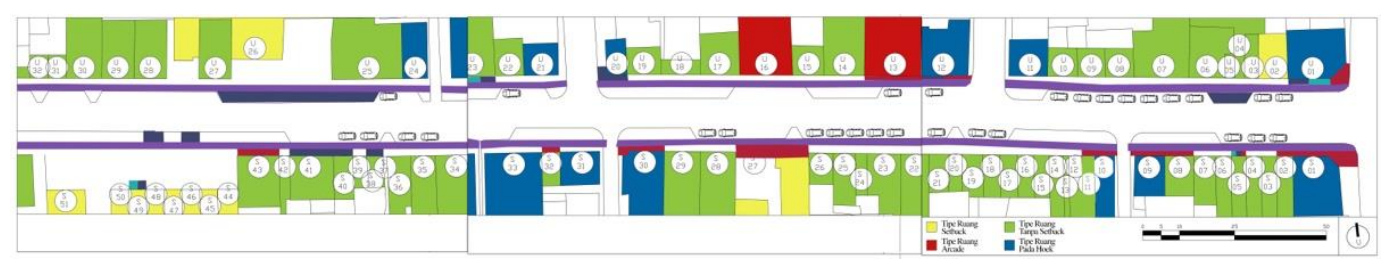

Gambar: Hubungan antar Tipologi Ruang Frontage \& Aktivitas Ruang Luar

Pada objek penelitian Jl. Jend. Sudirman ini, frontage yang ringan dan mengundang belum tentu menjadi pusat aktivitas. Tipologi ruang yang ada sangat memengaruhi hubungan antar frontage bangunan dan aktivitas yang berada pada ruang luar, pengguna akan memilih tempat untuk beraktivitas berdasarkan ruang yang tersedia. Pada titik-titik di mana karakter frontage bangunannya memiliki ruang luas dan akses visual dangkal, pengguna cenderung melakukan aktivitas bersosialisasi dan aktivitas pilihan, tidak melakukan aktivitas wajib. Frontage bangunan yang memiliki ruang besar yang dimaksud yaitu, ruang-ruang seperti hook jalan, bangunan dengan setback, dan bangunan dengan arkade. Semakin luas ruang yang ada, semakin banyak aktivitas di sekitarnya. Hal ini membuktikan bahwa pengunjung pada objek penelitian menyukai memerhatikan lingkungan sekitar (people watching). Hal ini menunjukkan bahwa tempat yang baik untuk menetap (good place for staying) pada kawasan ini ada pada titik titik dengan akses visual dangkal, sifat bangunan yang ringan namun tetap terdapat yang masif, dan ruang yang luas untuk memerhatikan sekitar seperti frontage dengan setback, frontage dengan arkade, dan bangunan yang berada pada hoek jalan. 


\section{DAFTAR PUSTAKA}

Anciaes, Paulo dkk. (2015). Mapping Pedestrian Accessibility and The Quality of Walking in an African City: Praia, Cape Verde. Turkey.

Ashihara, Yoshinobu. (1970). Exterior Design in Architecture. Van Nastrand. New York: Reinhold Co.

Alexander, C. (1977). A Pattern Language: Town, Building, Construction. New York: Oxford University Press.

Davies - Llewelyn. (2000). Urban Design Compendium. UK: English Partnerships \& The Housing Copporation

Gehl, Jan. (2010). Cities For People. Washington: Island Press.

Gehl, Jan. (2011). Life Between Buildings. Washington: Island Press.

Jacobs, Jane. (1961). The Death and Life of Great American City. New York: Vintage.

Krier, Rob. (1979). Urban Space. Michigan: Rizzoli International Publications.

Margono, Drs. S. Margono. (2004). Metodologi Penelitian Pendidikan. Jakarta: Rineka Cipta.

Shirvani, Hamid. (1985). The Urban Design Process. Melbourne: Van Nostrand Reinhold Company. Sugiyono. (2008). Metode Penelitian Kuantitatif, Kualitatif dan R\&D. Bandung: Penerbit Alfabeta. White, Edward T. (1999). Path, Portal, Place: Appreciating Public Space in Urban Environment. 